\title{
Germination, in vitro Propagation and Acclimatization in Lavandula Angustifolia
}

\author{
Ileana MICLEA ${ }^{1 *}$, Raluca CHIFOR ${ }^{1}$ \\ ${ }^{1}$ Department of Animal Reproduction, University of Agricultural Sciences and Veterinary Medicine, 3-5, \\ Mănăştur Street, 400372, Cluj-Napoca, Romania. \\ *Corresponding author, e-mail: ileana.miclea@usamvcluj.ro
}

Bulletin UASVM Animal Science and Biotechnologies 75(2)/ 2018

Print ISSN 1843-5262; Electronic ISSN 1843-536X

DOI:10.15835/buasvmcn-asb: 2018.0017

\begin{abstract}
This research focused on finding the best method for seed in vitro germination in Lavandula angustifolia and optimizing the medium for plant propagation. Seeds were sterilized and subjected to various treatments to break dormancy, then placed on half-strength MS $(1 / 2 \mathrm{MS})$ or distilled $\mathrm{H}_{2} \mathrm{O}+$ phytagel. Germination percentages were assessed and plantlets propagated on MS without growth regulators or with zeatin $(0.5,1,2 \mathrm{mg} / \mathrm{l}), 1 \mathrm{mg} / \mathrm{l} \mathrm{BA}$ $+0.5 \mathrm{mg} / \mathrm{l} \mathrm{IBA}, 2 \mathrm{mg} / \mathrm{l} \mathrm{BA}+1 \mathrm{mg} / \mathrm{l} \mathrm{IBA}$ or $3 \mathrm{mg} / \mathrm{l} \mathrm{BA}+1.5 \mathrm{mg} / \mathrm{l} \mathrm{IBA}$. After 8 weeks growth parameters were recorded and plants were acclimatized. Immersion in $20 \mathrm{mg} / 100 \mathrm{ml} \mathrm{GA} 3$ solution for 24 hours at $4^{\circ} \mathrm{C}$ was the most effective in breaking dormancy. Stratification at $4^{\circ} \mathrm{C}$ for 8 weeks and soaking in a solution of $0.5 \% \mathrm{H}_{2} \mathrm{O}_{2}$ at $23^{\circ} \mathrm{C}$ for 24 hours also proved beneficial but to a smaller degree. Half-strength MS was the best germination medium. Shoot development was the highest in MS supplemented with zeatin $(2$ or $1 \mathrm{mg} / \mathrm{l})$ while roots formed only in the control. Callus induction percentage was best in the presence of $3 \mathrm{mg} / \mathrm{l} \mathrm{BA}+1.5 \mathrm{mg} / \mathrm{l} \mathrm{IBA}$ but decreasing concentrations increased callus weight. Plant acclimatization was more successful in moss:sand - 1:2 than in vermiculite:perlite:sand - 2:2:1.
\end{abstract}

Keywords: in vitro propagation, Lavandula angustifolia, seed germination

\section{INTRODUCTION}

The genus Lavandula, of the family Labiatae (Lamiaceae), encompasses around 39 species, numerous hybrids and nearly 400 registered cultivars (Upson and Andrews, 2004). Lavenders are endemic to the Mediterranean region, the Arabian Peninsula, the Canary Islands and India and are extensively cultivated all over the world, particularly in France, Bulgaria, Russia, Italy, Spain, England, the United States, and Australia (Directorate Agricultural Information Services, Republic of South Africa, 2009).

Lavenders are widely used as ornamental and melliferous plants (Upson and Andrews, 2004) but they are mainly grown for their essential oils, which are highly valued in perfumery, cosmetics, food processing and alternative medicine (LisBalchin, 2002). Certain lavenders are thought to produce oils with antimicrobial, anticholinesterase and antioxidant activities (Costa et al., 2012, Hanamanthagouda et al., 2010). In addition to volatiles, they also generate antioxidants such as phytosterols, phenolic acids and flavonoids (Costa et al., 2011; Spiridon et al., 2011).

Lavenders may be propagated sexually or asexually, although reproduction through seeds is often slow. On the other hand, although vegetative propagation is necessary to produce genetically homogeneous individuals, multiplication via cuttings is slow and labour-intensive (Chawla, 2009). True lavender oil, consisting mainly of linalool and linalyl acetate, has a very variable composition due to the genetic instability of 
the oil-producing plants and variations due to temperature, water quantity, altitude, fertilizers, time of year, geographic distribution (Lis-Balchin, 2002). These limitations can be overcome using in vitro propagation methods under controlled environmental conditions so that valuable clones can be multiplied quickly. Thus it becomes possible to extract valuable metabolites throughout the year without seasonal constraints (Zuzarte et al., 2010). The quality of metabolites can be refined through genetic engineering which is possible only together with in vitro culture techniques (Kothari et al., 2010).

In vitro propagation has been developed for several species such as Lavandula angustifolia, $L$. latifolia, L. stoechas, L. dentata, L. pedunculata and the Lavandin hybrid (L. angustifolia $x$ L. latifolia) with the purpose of characterizing and improving secondary metabolite production (Andrys et al., 2018; Gonçalves and Romano, 2013; Segura and Calvo, 1991). However, the protocol for establishing and propagating species belonging to the Lavandula genus still needs improving to increase survival rates of plants acclimatized to field conditions.

The focus of this research has been to find the best method for seed germination in L. angustifolia and optimize the most suitable medium for the in vitro multiplication of plants.

\section{MATERIALS AND METHODS}

L. angustifolia seeds were obtained from an authorized seller (Kertimag Romania SRL, ClujNapoca). Unless otherwise stated all reagents were acquired from Duchefa Biochemie, The Netherlands.

Seed germination was attempted on the following media: MS medium (Murashige and Skoog, 1962) with half-strength macronutrients, half-strength micronutrients and full-strength vitamins $(1 / 2 \mathrm{MS})$ or distilled water solidified with phytagel $\left(\mathrm{dH}_{2} \mathrm{O}+\right.$ phytagel). Plant multiplication took place using full strength MS without growth regulators or supplemented with zeatin $(0.5 \mathrm{mg} / \mathrm{l}, 1$ $\mathrm{mg} / \mathrm{l}, 2 \mathrm{mg} / \mathrm{l}$ ) or combinations of 6-benzyladenine (BA) and indole-3-butyric acid (IBA): $1 \mathrm{mg} / \mathrm{l} \mathrm{BA}+$ $0.5 \mathrm{mg} / \mathrm{l} \mathrm{IBA}, 2 \mathrm{mg} / \mathrm{l} \mathrm{BA}+1 \mathrm{mg} / \mathrm{l}$ IBA or $3 \mathrm{mg} / \mathrm{l} \mathrm{BA}$ $+1.5 \mathrm{mg} / \mathrm{l} \mathrm{IBA}$.

All types of MS based media were enriched with $30 \mathrm{~g} / \mathrm{l}$ sucrose, solidified with $5 \mathrm{~g} / \mathrm{l}$ phytagel and $\mathrm{pH}$ was adjusted to 5.6-5.7 before autoclaving at $121^{\circ} \mathrm{C}$ for $20 \mathrm{~min}$. For the seed germination medium phytagel was added to distilled water, the $\mathrm{pH}$ was corrected and the medium underwent sterilization. Following cooling growth regulators were added to the media as needed.

Seeds were surface sterilized by immersion in a $20 \%$ solution of commercial bleach for 10 minutes. Afterwards, they were washed in sterile water 3 times and separately subjected to various treatments to break dormancy: immersion in a 20 $\mathrm{mg} / 100 \mathrm{ml}$ gibberellic acid (GA3) (Sigma-Aldrich, Germany) solution for 24 hours at $4^{\circ} \mathrm{C}$, scraping with $125 \mu \mathrm{m}$ grain sandpaper for approximately 10 , soaking in $0.5 \% \mathrm{H}_{2} \mathrm{O}_{2}$ at $23^{\circ} \mathrm{C}$ for 24 hours, freezing at $-20^{\circ} \mathrm{C}$ for 48 hours or stratification at $4^{\circ} \mathrm{C}$ for 8 weeks. Seeds were placed in Petri dishes on $1 / 2 \mathrm{MS}$ or $\mathrm{dH}_{2} \mathrm{O}+$ phytagel immediately or after the requisite waiting times placed in the growing chamber at $20-25^{\circ} \mathrm{C}$ under a $18 / 6 \mathrm{~h}$ light/dark regime provided by cool white fluorescent lamps with a light intensity of $40 \mu \mathrm{mol} / \mathrm{m}^{2} / \mathrm{s}$. Four weeks later the percentage of germinated seeds was assessed. Five repetitions using a total of 160 seeds were made for each treatment.

The resulting seedlings were used to establish an in vitro stock of plants that were subsequently employed in the multiplication experiment. Shoots (10-15 $\mathrm{mm}$ in length) were transferred to MS with or without growth regulators and kept for 8 weeks in the same conditions as the seeds. At the end of this time the number of shoots, shoot height $(\mathrm{cm})$, the number of roots, root length $(\mathrm{cm})$, callus induction percentage $(\%)$ and callus weight (g) were recorded. These measurements were used to calculate number of shoots and shoots per explant and also callus weight per explant. Seven to eight plantlets per vessel were inoculated for each treatment and treatments were repeated 5 times. For both germination and multiplication experiments data were subjected to analysis of variance and means were separated using the Tuckey test with $\mathrm{p}<0.05$ being considered statistically significant. These were performed using GraphPad InStat version 3.05 (GraphPad Software, San Diego California, USA). For acclimatization, rooted plantlets were washed with water to rinse away any media. They were placed in plastic minigreenhouses filled with a mixture of Sphagnum moss:sand at a ratio of 1:2 or a mixture of vermiculite:perlite:sand at a ratio 
Tabel 1. Effect of dormancy breaking treatment and culture medium on germination in L. angustifolia

\begin{tabular}{ccc}
\hline Dormancy breaking treatment & Culture medium & Germinated seeds (\%) \\
\hline \multirow{2}{*}{$\mathrm{GA} 3$} & $1 / 2 \mathrm{MS}$ & $77.50 \pm 3.75 \mathrm{a}$ \\
\cline { 2 - 3 } & $\mathrm{dH}_{2} \mathrm{O}+$ phytagel & $71.71 \pm 6.15 \mathrm{ac}$ \\
\cline { 2 - 3 } Sand paper & $1 / 2 \mathrm{MS}$ & $30.10 \pm 6.13 \mathrm{bg}$ \\
\cline { 2 - 3 } & $\mathrm{dH}_{2} \mathrm{O}+$ phytagel & $13.13 \pm 3.62 \mathrm{be}$ \\
\cline { 2 - 3 } $0.5 \% \mathrm{H}_{2} \mathrm{O}_{2}$ & $1 / 2 \mathrm{MS}$ & $49.38 \pm 1.17 \mathrm{~d}$ \\
\hline \multirow{2}{*}{$-20^{\circ} \mathrm{C}$} & $\mathrm{dH}_{2} \mathrm{O}+$ phytagel & $21.88 \pm 5.93 \mathrm{bfg}$ \\
\cline { 2 - 3 } & $1 / 2 \mathrm{MS}$ & $8.21 \pm 1.32 \mathrm{ef}$ \\
\hline \multirow{2}{*}{ Stratification at $4{ }^{\circ} \mathrm{C}$} & $\mathrm{dH}_{2} \mathrm{O}+$ phytagel & $8.13 \pm 1.25 \mathrm{ef}$ \\
\cline { 2 - 3 } & $1 / 2 \mathrm{MS}$ & $36.79 \pm 3.71 \mathrm{dg}$ \\
\hline
\end{tabular}

Note: Values expressed are mean \pm standard error of the mean (SEM). Different letters between means within the same column denote significant differences $(\mathrm{p}<0.05)$.

Tabel 2. Effects of growth regulators on plant multiplication and callus formation in L. angustifolia

\begin{tabular}{ccccccc}
\hline Treatment & $\begin{array}{c}\text { Number of } \\
\text { shoots/explant }\end{array}$ & $\begin{array}{c}\text { Shoot height } \\
(\mathrm{cm})\end{array}$ & $\begin{array}{c}\text { Number of } \\
\text { roots/explant }\end{array}$ & $\begin{array}{c}\text { Root length } \\
(\mathrm{cm})\end{array}$ & $\begin{array}{c}\text { Callus induction Callus weight } \\
\text { percentage }(\%)\end{array}$ & $\begin{array}{c}\mathrm{g}) \\
(\mathrm{g})\end{array}$ \\
\hline Control & $4.13 \pm 0.96 \mathrm{a}$ & $1.85 \pm 0.13 \mathrm{ac}$ & $0.53 \pm 0.30 \mathrm{a}$ & $1.13 \pm 0.66 \mathrm{a}$ & $0.00 \pm 0.00 \mathrm{a}$ & $0.00 \pm 0.00 \mathrm{a}$ \\
\hline $0.5 \mathrm{mg} / \mathrm{l}$ zeatin & $4.57 \pm 1.06 \mathrm{a}$ & $1.94 \pm 0.05 \mathrm{ac}$ & $0.00 \pm 0.00 \mathrm{~b}$ & $0.00 \pm 0.00 \mathrm{~b}$ & $0.00 \pm 0.00 \mathrm{a}$ & $0.00 \pm 0.00 \mathrm{a}$ \\
\hline $1 \mathrm{mg} / \mathrm{l} \mathrm{zeatin}$ & $10.61 \pm 1.27 \mathrm{~b}$ & $2.10 \pm 0.09 \mathrm{a}$ & $0.00 \pm 0.00 \mathrm{~b}$ & $0.00 \pm 0.00 \mathrm{~b}$ & $0.00 \pm 0.00 \mathrm{a}$ & $0.00 \pm 0.00 \mathrm{a}$ \\
\hline $2 \mathrm{mg} / \mathrm{l} \mathrm{zeatin}$ & $11.12 \pm 2.33 \mathrm{bc}$ & $1.89 \pm 0.06 \mathrm{ac}$ & $0.00 \pm 0.00 \mathrm{~b}$ & $0.00 \pm 0.00 \mathrm{~b}$ & $0.00 \pm 0.00 \mathrm{a}$ & $0.00 \pm 0.00 \mathrm{a}$ \\
\hline $\begin{array}{c}1 \mathrm{mg} / \mathrm{l} \mathrm{BA}+0.5 \\
\mathrm{mg} / \mathrm{l} \mathrm{IBA}\end{array}$ & $5.05 \pm 0.88 \mathrm{a}$ & $1.64 \pm 0.10 \mathrm{ac}$ & $0.00 \pm 0.00 \mathrm{~b}$ & $0.00 \pm 0.00 \mathrm{~b}$ & $71.21 \pm 12.48 \mathrm{~b}$ & $7.42 \pm 1.73 \mathrm{~b}$ \\
\hline $\begin{array}{c}2 \mathrm{mg} / \mathrm{l} \mathrm{BA}+1 \\
\mathrm{mg} / \mathrm{l} \mathrm{IBA}\end{array}$ & $2.13 \pm 0.46 \mathrm{a}$ & $1.38 \pm 0.16 \mathrm{bd}$ & $0.00 \pm 0.00 \mathrm{~b}$ & $0.00 \pm 0.00 \mathrm{~b}$ & $79.24 \pm 5.72 \mathrm{bc}$ & $6.23 \pm 1.51 \mathrm{~b}$ \\
\hline $\begin{array}{c}3 \mathrm{mg} / \mathrm{l} \mathrm{BA}+1.5 \\
\mathrm{mg} / \mathrm{l} \mathrm{IBA}\end{array}$ & $2.91 \pm 0.58 \mathrm{a}$ & $1.54 \pm 0.09 \mathrm{~cd}$ & $0.00 \pm 0.00 \mathrm{~b}$ & $0.00 \pm 0.00 \mathrm{~b}$ & $95.78 \pm 2.5 \mathrm{c}$ & $5.35 \pm 0.61 \mathrm{~b}$ \\
\hline
\end{tabular}

Note: Values expressed are mean \pm standard error of the mean (SEM). Different letters between means within the same column denote significant differences $(\mathrm{p}<0.05)$.

of $2: 2: 1$ and kept at $20-25^{\circ} \mathrm{C}$ and under a $18 / 6 \mathrm{~h}$ light/dark regime. After 8 weeks the number of living plants was counted.

\section{RESULTS AND DISCUSSION}

In $L$. angustifolia immersion in GA3 was the most effective in breaking dormancy (Tab. 1.) with seeds starting to germinate after 2 weeks and the resulting percentages being significantly higher than for any of the other treatments (77.50\%). After this treatment half strength MS yielded slightly better germination percentages than distilled water solidified with phytagel. Germination was promoted by cooling seeds at $4^{\circ} \mathrm{C}$ and plating them in both types of media but also by soaking in $\mathrm{H}_{2} \mathrm{O}_{2}$ followed by incubation in $1 / 2 \mathrm{MS}$. The poorest results for breaking dormancy were recorded if seeds were frozen at $-20^{\circ} \mathrm{C}$ for 48 hours. Overall, seeds germinated better when placed in $1 / 2$ MS than in distilled water and phytagel. However, this situation was reversed when they were stratified at $4^{\circ} \mathrm{C}$ for 8 weeks.

Our results are in accordance with those of Mala et al. (2011) and Aoyama et al., (1991) who recorded the best germination when $L$. angustifolia seeds were treated with GA3 for 24 
hours. However, in our case the percentages of germinated seeds are higher. Parallel to the work of Dobrowolska and Zawadzińska (2014) in our experiment a 8 week stratification for the seeds of L. angustifolia resulted in good plant emergence. In the experiments of Segura and Calvo (1991) the best results are obtained by soaking seeds in $0.5 \%$ $\mathrm{H}_{2} \mathrm{O}_{2}$, which was the third best option in our case. With respect to the medium used for germination, a mixture of water and agar has been proposed as the most effective by Segura and Calvo (1991). This is in contrast with the results of the current research and the work of Shams Ardekani et al. (2007) who established $1 / 2 \mathrm{MS}$ as the better medium.

When compared with the other growth regulators shoot formation was significantly better in MS supplemented with $2 \mathrm{mg} / \mathrm{l}$ zeatin or 1 $\mathrm{mg} / \mathrm{l}$ zeatin (Tab. 2.). Also, the tallest shoots were measured when $2 \mathrm{mg} / \mathrm{l}$ zeatin was added to MS. The poorest shoot formation and height could be recorded in the presence of $2 \mathrm{mg} / \mathrm{l} \mathrm{BA}+1 \mathrm{mg} / \mathrm{l}$ IBA and $3 \mathrm{mg} / \mathrm{l} \mathrm{BA}+1.5 \mathrm{mg} / \mathrm{l} \mathrm{IBA}$. On the other hand, the presence of growth regulators was not needed to induce the emergence of roots.

Shoot regeneration in L. angustifolia has been promoted by BA added to MS at a concentration of $2 \mathrm{mg} / \mathrm{l}$ (Mokhtarzadeh et al., 2013; Parkash and Singh, 2013). Other researchers have proposed WPM medium supplemented with $0.1 \mathrm{mg} / \mathrm{l} \mathrm{BA}$ as the best for shoot growth (TienVinh et al., 2017). Although BA and other cytokinins such as kinetin have been used extensively for shoot multiplication in L. angustifolia (Chishti et al., 2006), to our knowledge this is the first time zeatin is employed in propagation.

Culture in MS supplemented with BA and IBA was the only to lead to the development of callus while both zeatin and the control had no effect. Gradually increasing concentrations of BA and IBA improved callus induction percentage up to $95.78 \%$ for $3 \mathrm{mg} / \mathrm{l} \mathrm{BA}+1.5 \mathrm{mg} / \mathrm{l}$ IBA but reduced its weight. The largest amount of callus was recorded for the lowest concentration: $1 \mathrm{mg} / \mathrm{l} \mathrm{BA}$ $+0.5 \mathrm{mg} / \mathrm{l} \mathrm{IBA}$ (7.42 g).

The formation callus on this type of growth regulator combination is in contrast with the results of Leelavathi and Kuppan (2013) who reported using a cytokinin (BA) and an auxin (NAA - $\alpha$-naphthaleneacetic acid) to induce multiple shoots instead of callus in L. angustifolia. It is interesting to note that combining BA and NAA, an auxin wich induces stronger effects resulted in shoot formation while IBA which is considered the weaker plant regulator produced small shoots and large quantities of calllus. For L. angustifolia Falk et al. (2009) described a method based on thidiazuron (TDZ) to stimulate the development of callus on incised leaf tissues within 2 weeks, followed by spontaneous shoot organogenesis after 2-4 additional weeks. In our research shoots also formed when BA and IBA were added to the medium but their number was much smaller than the one recorded for zeatin.

During their study Ghiorghiță et al. (2009) observed that callus formed on medium supplemented with $1 \mathrm{mg} / \mathrm{l} \mathrm{BA}$ and $0.5 \mathrm{mg} / \mathrm{l} \mathrm{GA3}$ and cultured further on medium with $0.2-0.5$ $\mathrm{mg} / \mathrm{l}$ BA generated multiple shoots. In our case shoots did not form on callus perhaps because GA3 was not employed in the initial multiplication medium and we did not subculture the callus repeatedly. Also, our BA concentrations were higher than those used by Ghiorghiță et al.. Higher concentrations of the same growth regulators: 10 $\mathrm{mg} / \mathrm{l} \mathrm{BA}$ combined with $0.5 \mathrm{mg} / \mathrm{l} \mathrm{GA3}$ resulted in better shoot multiplication, callus formation and survival percentage (De Bona et al., 2011). In this research we found a mixture of cytokinin and auxin to be the best for the development of callus at high induction percentages.

At the end of our experiment plants were successfully acclimatized in both mixtures but vermiculite:perlite:sand resulted in a larger percentage of surviving plants $(91.66 \%)$ than the combination of Sphagnum moss:sand (85.5\%).

\section{CONCLUSION}

Several methods could be used to successfully break seed dormancy in L. angustifolia, the best among them being immersion in $20 \mathrm{mg} / 100 \mathrm{ml}$ GA3 solution for 24 hours at $4^{\circ} \mathrm{C}$ which should be coupled with $1 / 2 \mathrm{MS}$ as germination medium. Zeatin at $2 \mathrm{mg} / \mathrm{l}$ or $1 \mathrm{mg} / \mathrm{l}$ was the most favourable for generating good shoot development while roots formed only in medium without plant growth regulators. The best callus induction was achieved by adding $3 \mathrm{mg} / \mathrm{l} \mathrm{BA}$ and $1.5 \mathrm{mg} / \mathrm{l}$ IBA to MS medium. 


\section{REFERENCES}

1. Andrys, D., Adaszyńska-Skwirzyńska, M., Kulpa, D. (2018). Essential oil obtained from micropropagated lavender, its effect on HSF cells and application in cosmetic emulsion as a natural protective substance. Nat Prod Res 32(7), 849-853.

2. Aoyama, E., Ono, E., Furlan, M. (1996). Germination study of lavender seeds. Scientia-Agricola 53(2-3), 267-272.

3. Bona, C.M., Reinhart, V., Biasi, L.A, Zanette, F. (2011). Lavandula dentata and Lavandula angustifolia in vitro organogenesis. Plant Cell Cult Micropropag 7(2), 66-70.

4. Chawla, H.S. (2009). Introduction to plant biotechnology. (3rd ed). Science Publishers, Enfield, USA.

5. Chisht,i N., Kaloo, Z.A., Shawl, A.S., Sultan, P. (2006). Rapid in vitro clonal propagation of Lavandula officinalis Chaix a multipurpose plant of industrial importance. Pakistan Journal of Biological Sciences 9(3), 514-518.

6. Costa, P., Gonçalves, S., Andrade, P.B., Valentão, P., Romano, A. (2011). Inhibitory effect of Lavandula viridis on Fe2+induced lipid peroxidation, and antioxidant and anticholinesterase properties. Food Chem 126, 1779-1786.

7. Costa, P., Grosso, C., Gonçalves, S., Andrade, P.B., Valentão, P., Romano, A. (2012). Supercritical fluid extraction and hydrodistillation for the recovery of bioactive compounds from Lavandula viridis L'Hér. Food Chem 135, 112-121.

8. Directorate Agricultural Information Services, Department of Agriculture, Forestry and Fisheries, Pretoria, Republic of South Africa. A report on Essential oil crops: Production guidelines for lavender. (2009). http:// www.nda.agric.za/docs/brochures/essoilslavender.pdf Accessed 13.08.2018.

9. Dobrowolska, A., Zawadzińska, A., (2014). The influence of stratification on seedling emergence and growth of narrow-leaved lavender and its cultivars. International Journal of Plant \& Soil Science 3(8), 948-958.

10. Ghiorghiță, G., Maftei, D-E., Nicuţă, D. (2009). Some aspects concerning the in vitro reaction of Lavandula angustifolia L. Propag Ornamental Plants 9(1), 47-49.

11. Hanamanthagouda, M.S., Kakkalameli, S.B., Naik, P.M., Nagella, P., Seetharamareddy, H.R., Murthy, H.N. (2010). Essential oils of Lavandula bipinnata and their antimicrobial activities. Food Chem 118, 836-839.

12. Kothari, S.L., Joshi, A., Kachhwaha, S., Ochoa-Alejo, N. (2010). Chilli peppers - a review on tissue culture and transgenesis. Biotechnol Adv 28, 35-48.

13. Leelavathi, D., Kuppan, N. (2013). Protocol for rapid clonal multiplication using in vitro apical bud of Lavandula angustifolia. IOSR Journal of Pharmacy and Biological Sciences 7(3), 96-98.

14. Lis-Balchin, M. (2002). Lavender: The Genus Lavandula. Taylor \& Francis, London.

15. Mala, F., Ahmad, P., Shrivastava, P.N. (2011). In vitro seed germination studies of Lavandula officinalis Chaix. Biomedical \& Pharmacology Journal 4(1), 223-226.

16. Mokhtarzadeh, S., Hajyzadeh, M., Ahmad, H.A., Khawar, K.M. (2013). The problems in acclimatisation of in vitro multiplied plants of Lavandula angustifolia Miller under field conditions. Acta Hortic 988, 71-76.

17. Murashige, T., Skoog, F. (1962). A revised medium for rapid growth and bioassays with tobacco tissue cultures. Physiol Plant 15, 474-497.

18. Parkash, V., Singh, H. (2013). Lavandula angustifolia L. (Lavender): An important aromatic medicinal shrub and its in vitro micro-propagation for conservation. Journal of Agricultural Technology 9(3), 91-702.

19. Segura, J., Calvo, M.C. (1991). Lavandula spp. (Lavender): In vitro culture, regeneration of plants, and the formation of essential oils and pigments. In Bajaj, Y.P.S (Eds), Biotechnology in Agriculture and Forestry vol 15, Medicinal and Aromatic Plants III, vol. 43, 283-310, Springer, Cham.

20. Shams Ardekani, M.R., Linleyb, P.A., Harkissb, K.J., Mohagheghzadehc, A., Gholamic, A., Mosaddegh, M. (2007). Biotransformation of monoterpenoids by suspension cultures of Lavandula angustifolia. Iranian Journal of Pharmaceutical Sciences 3(2), 93-100.

21. Spiridon, I., Colceru, S., Anghel, N., Teaca, C.A., Bodirlaua, R., Armatu, A. (2011). Antioxidant capacity and total phenolic contents of oregano (Origanum vulgare), lavender (Lavandula angustifolia) and lemon balm (Melissa officinalis) from Romania. Nat Prod Res 25, 16571661.

22. TienVinh, D., Hoa, M.T., Khai, P.C., Minh, T.V. (2017). Micropropagation of lavender (Lavandula angustifolia). Journal of Innovations in Pharmaceutical and Biological Sciences 4(2), 7-11.

23. Upson, T., Andrews, S. (2004). The genus Lavandula. Timber Press, Portland.

24. Zuzarte, M.R., Dinis, A.M., Cavaleiro, C., Salgueiro, L.R., Canhoto, J.M. (2010). Trichomes, essential oils and in vitro propagation of Lavandula pedunculata (Lamiaceae). Ind Crop Prod 32, 580-587. 